\title{
Montesquieu in Poland by Majer Korzennik ${ }^{1}$
}

\author{
Anna Jarmuszkiewicz \\ (Polska Akademia Umiejętności) \\ e-mail: jarmuszkiewicza@gmail.com
}

Key words: Judaica, Montesquieu, orphan works, Jagiellonian University

\begin{abstract}
The article is devoted to a brief biography, scientific achievements and views of Meir Korzennik, a writer, publicist and Ph.D. laureate of the Jagiellonian University, as well as a teacher and tutor of Jewish youth. The study describes his doctoral thesis on the reception of Montesquieu in Poland, and addresses the legal category of orphan works.
\end{abstract}

\section{The Background}

The interwar period is a special time in Polish history. Czesław Miłosz called this period a mythical, unvisited and idealized land. In the Second Polish Republic, with its multicultural, multinational character, Jews constituted about $10 \%$ of the population, and this percentage was much higher in academia. Analyzing the history of universities reveals the problems of the era on the financial, legal, and social levels. This article is an attempt to show only a mere fragment of the picture of the Jewish intellectual community associated with the Jagiellonian University during this period. A shred of that lost world is revealed through the prism of Majer Korzennik's doctoral dissertation.

In the Second Polish Republic, the teaching cycle at universities was significantly different from what we now know. It should be recalled that until 1926 studies at the Faculty of Philosophy were completed only by the discharge ${ }^{2}$ (there was no requirement to write a master's thesis). As Anna Smywińska-Pohl and Ewa Chudoba wrote, "then the graduate could (but did not have to) take teaching exams (which entitles him to teach in secondary school), or strict exams (i.e. rigorosis that allowed him

\footnotetext{
${ }^{1}$ The article was financed by the National Science Center under the agreement No. UMO-2014/13/N/ HS2/02813.

${ }^{2}$ Certificate of completion / vote of approval / completion of studies without defending the degree.
} 
to apply for a doctoral degree)." ${ }^{3}$ Therefore, presence at a university was not always associated with leaving a trace in the form of a master's thesis.

Jewish thinkers who began their adult life in the interwar period are usually not known to a wider audience. This generation of people associated with the Jagiellonian University is certainly recognized by Debora Vogel and Adam (Abraham) Landman. However, they do not exhaust the wealth of that bygone era. It should be noted that more complete knowledge can be obtained by looking at "peripheral people," i.e. authors, of which little has been written so far, whose achievements are not widely known, and access to that resources is significantly impeded, due to both the condition of the preserved texts and legal concerns. ${ }^{4}$

Until 1945 the Faculty of Philosophy at the Jagiellonian University undertook research in a very wide range of fields and disciplines. As Mariusz Kulczykowski points out: "Everything that was not theology, law, medicine, and in time natural sciences and pharmacy, was located at the Faculty of Philosophy." "This means that in the faculty one could earn degrees and academic titles in the fields of philosophy, psychology, pedagogy, foreign languages (classical and modern), Polish philology, zoology, botany, mathematics, physics, chemistry, and biology.

Jewish students often chose philosophy and Polish philology as their subject of study at the university in Krakow. One of the students of Jewish origin who studied at the Faculty of Philosophy of the Jagiellonian University in 1922 was Majer Korzennik. His scientific profile, and later also his prominent journalistic output, deserve further consideration.

\section{About Korzennik}

Majer Pinkas Korzennik, author of the doctoral thesis "Montesquieu in Poland," was born on February 18, 1902, in Czermna, Jasło District. He graduated from elementary school in Biecz in 1913. In 1922, as an extramural student, he passed the matriculation exam at the State Gymnasium V in Krakow. He enrolled at the Faculty of Philosophy of the Jagiellonian University for the academic year 1922/23, where he majored in Polish philology, with a minor in French philology. In 1927 he passed the exam at the Pedagogical College in Krakow, and he graduated in 1930. It is known that in 1933 he married Bolesława Zuzanna Ingber. The war and post-war fate of Majer Korzennik, however, remains unknown.

One important factor in investigating traces left by Korzennik is the spelling of both his first and last names. His surname varies as Korzennik and Korzenik, while the orthography of his first name poses greater difficulties. It is most often rendered as Meir or

\footnotetext{
${ }^{3}$ Chudoba, Smywińska-Pohl 2017: 27.

${ }^{4}$ The new law, which has been in force since 2015 , has created new opportunities for dealing with the work of missing authors. The remaining traces of them are called orphan works. The term and its meaning will be explained at the end of this article.

${ }^{5}$ Kulczykowski 2004: 37.
} 
Majer, but there are at least 12 variants, including Meier, Mayer and Myer, together with their declension forms. It should be assumed that in official relations he used a spelling derived from a record used in civil registry files, created during the Austrian administration in Galicia - hence the Germanized spelling. This is confirmed by the entry in the official documents of the Jagiellonian University and the presence of such a spelling on the list of lecturers of the prestigious King Jan III Sobieski High School in Krakow. As can be seen from the Memorial Book of the Third Grammar School (at present, II High School of King Jan III Sobieski 1885-1985), in 1932-1933 Majer Korzennik was an apprentice a teacher of the Polish language. ${ }^{6}$

The life of the author of the monograph about Polish Montesquieu was not limited to the academic sphere. Korzennik was involved in the education of Jewish youth, devoting his attention, for example, to maritime preparation at the seafaring academy for Jewish youth that existed in Gdynia in the 1930s. The creation of a kibbutz in Gdynia was an initiative of the "Zebulun" organization, which among their many activities dealt with the implementation and dissemination of maritime awareness among Zionistically oriented Jews. The programme included fishing courses and sailing camps by the sea. The implemented program was in line with the Polish guidelines of the State Office of Physical Education and Military Preparation. Korzennik wrote in a text entitled "The Maritime Preparation of Jewish Youth"7:

After staying at such a camp, which took place in 1935 in Swarzewo (a village four kilometres south of Władysławowo, in Puck County) one of the Halutzas went to England, where he worked on the construction of ships, and several others found employment in Palestinian shipping. The next camp, the second in the history of "Zebulun" and the sea hachshara in Gdynia, took place in $1936 .^{8}$

Korzennik described how the school's philosophy favoured both religious and secular learning:

We often encounter words from the Bible and the Prophets in Polish language lessons. Studying with the Talmud facilitates learning in exact sciences. History or biology lessons not only illustrate civic or human examples in general, but also bring praise to God [...]. Learn by faith $[\ldots]$ faith through science! In this way, the essence and real scientific and educational results of this Jewish high school, the only one of its kind in Poland, can be formulated. ${ }^{9}$

Korzennik was also an active publicist. According to Eugenia Prokop-Janiec, ${ }^{10}$ he published works in, among others, his Literatura i Sztuka supplement of Krakow's Nowy Dziennik, as well as in Kurier Literacko-Naukowy, and in Tygodnik Żydowski in Tarnów.

\footnotetext{
${ }^{6}$ Vide Księga Pamiątkowa 1984.

${ }^{7}$ Vide M. Korzennik, "Przysposobienie morskie młodzieży żydowskiej”, Nasz Przegląd, 13.06.1936, no. 174 .

${ }^{8}$ Vide Gregorowicz Hachszara na ziemiach polskich, https://histmag.org/Hachszara-na-ziemiach-polskich-6131 (Accessed: 14 November 2018).

${ }^{9}$ Korzennik 1937: 104-105.

${ }^{10}$ Vide Prokop-Janiec 1992: 35.
} 
It was on its pages that he got into a heated discussion with Roman Brandstaetter, rejecting this author and his viewpoint. ${ }^{11}$ Brandstaetter recognized that Polish-Jewish poets were Jews who settled in Polish culture, not Poles of the Mosaic faith. At the same time, he attacked assimilated writers and claimed that "national Polish-Jewish poetry should raise not only Jewish themes but rather contain and propagate the ideals of national revival." 12 Korzennik accused the later author of Other Flowers of St. Francis of "megalomania, impudence, [and] irresponsible artistic pieces."'13

\section{"Montesquieu in Poland"14}

The doctoral dissertation, submitted for evaluation in 1931, garnered highly favourable opinions from reviewers. Windakiewicz (at the same time the work's promoter) noted in his review:

The work of Mr. Majer Korzennik "Montesquieu in Poland" shows in Chapter III the influence of Montesquieu on Polish journalism in the second half of the $18^{\text {th }}$ century, and in chapter IV on three eminent writers: Niemirski, Staszic and Krasicki. The main chapters were preceded by an introduction about the relations of the great statesman with Poland and Poles and the dissemination of information about him in Poland. He finished the additional chapter about the short story Temple in Knidos, which had a unique success with us. The work is based on a good knowledge of Montesquieu's works and an urgent search for sources. He draws up a $[\ldots]$ theme from the history of incorporating French into literature and the emergence of our educational trend. The dissertation is conscientious, well-arranged and conducted. Greatly occupying, it offers many new statements and observations and gives the candidate the full right to apply for a doctoral degree [February 3, 1931].

In 1935 Korzennik, together with Laskowski and Nowak, published "Bibliographic materials for the writings of Professor Stanisław Windakiewicz" in Pamiętnik Literacki. Lehr-Spławiński also noted many merits of the work:

Work by Majer Korzennik titled "Montesquieu in Poland" gives the impression of a serious work, based on a thorough mastery of literature and reflection on issues. In terms of form, style and language it is impeccable. In particular, I share the opinion of Prof. Windakiewicz that it can be considered a dissertation.

In the summer of 1931, on 26 June, Korzennik took his final examinations in Polish philology and French philology (the main rigor) and received an insufficient grade from the examination committee: Professors Dyboski (presiding) Windakiewicz,

\footnotetext{
${ }^{11}$ Vide ibid.: 42.

${ }^{12}$ Ibid.

${ }^{13}$ M. Korzennik, "Skąd i po co ten wstęp (À propos pewnej sprawy nieosobistej)”, Tygodnik Żydowski

${ }^{14}$ Archiwum UJ, WF II 505.
} 1933, no. 33 . 
Lehr-Spławiński, and Folkierski. The second time, before the same committee, on December 5, 1931, he received a sufficient result. In the case of an additional subject exam, in philosophy, which took place on June 20, 1931 with a committee composed of Professors Dyboski (chairman) Rubczynski, and Heinrich, Korzennik received a perfect result.

"Montesquieu in Poland" addresses the issue of reception of the author's work. Montesquieu was born on January 18, 1689 in La Brède and died on February 10, 1755 in Paris. This French philosopher, lawyer, freemason and writer of the Enlightenment is known above all as the author of the multi-volume work On the Spirit of the Laws [De l'esprit des lois] (1748), in which he describes and comments on contemporary political systems of the world. He is also known for being the creator and advocate of the concept of three divisions of power.

The dissertation analyses the reception of the entire output of Montesquieu, who is best known as the author of treatises in the field now classified as political and legal doctrine. Korzennik refers to the whole of the author's writings, including genres such as drama and epistolography, and he does so insightfully.

The text of the dissertation, preserved in the collections of the Archives of the Jagiellonian University in the form of typescript, probably has not been published anywhere. Nevertheless, according to a bibliographic note contained in the Archivum neophilologicum, fragments of Korzennik's dissertation found their reflection in the Kurier Literacko-Naukowy supplement to Ilustrowany Kurier Codzienny, a daily published in Krakow. However, the indicated bibliographical location cannot confirmed by archived copies of this newspaper.

In comparison to others from this period the doctorate is extensive: at over 175 pages, including bibliography, it consists of an introduction and five basic chapters. The first chapter, entitled Relations between Montesquieu and Poland and his remarks on the Polish-Lithuanian Commonwealth, refers to the biographical elements of Montesquieu and the Poles of his time. Choosing the time interval, Korzennik decided to focus on the period between the French author's life and the 1830s. The author describes, based on rich source material, the relations of the great Frenchman with representatives of the Polish court - in this context one should mention King Stanisław Leszczyński staying in France (Korzennik looks for Leszczyński's influence on the shape of Montesquieu's writings) and Montesquieu's meeting with young people in Paris, and the future King Stanisław August Poniatowski, as well as to other interactions with Poles. Korzennik also analyzes the Frenchman's knowledge of Poland from that era, reviewing the historical sources about the Polish-Lithuanian Commonwealth available at that time. Then, Korzennik examines the opinions about our country contained in the philosopher's writings: "In Poland, Montesquieu sees first of all far-reaching social inequality, lack of equality, excessive privileges of the nobility [...]" (p. 12).

In the second chapter, "Beginnings of the Knowledge of Montesquieu in Poland," the author accurately reproduces the path the thought of the writer of the Enlightenment had to pass before it was accepted and internalized by the minds of the Polish elite. The author refers to education of that era, comparing the author's reception in various social environments, from the scholastic Jesuits to the more progressive Piarists from Collegium Nobilum, with Konarski at the forefront. He then describes the political life 
and the wider reception of Montesquieux's works and thoughts, especially the treatise De l'esprit des loix or The Spirit of the Laws. The threads referred to in this chapter find a full and very detailed development in the next chapter.

The third chapter, "Montesquieu in Journalism and Booklet Literature of the $18^{\text {th }}$ Century" perfectly reflects the dynamics of the exchange of ideas of various intellectual and political parties of the Polish state, along with existing sympathies and antagonisms. This chapter, the most extensive, is divided into four subsections: opponents and defenders of Montesquieu from a religious position; echoes of Montesquieu's views in legal-political and social journalism; Polish believers of the school of laws of nature towards the Spirit of the Laws; and Montesquieu's slogans and ideals in the field of legislative actions.

The penultimate chapter "Traces of Montesquieu's Influence on the Great Reformers" is divided into three parts, each devoted to Konarski, Staszic and Krasicki. In the section on Konarski, Korzennik introduces the Piarist as a promoter of Montesquieu, while he notices his "indistinct" attitude towards the presented parliamentary system. Finally, he refers to the "remarks about the Romans" contained in Konarski's On the Means of Effective Counsels. Korzennik does not omit the polemics of Rzewuski and Konarski. In the case of Stanisław Staszic, the dissertation takes up the topic of Contemporary Voice about Dependencies, Comment on the Life of Jan Zamoyski and Staszic's comments on trade or taxes. In the last subsection, devoted to the works of Ignacy Krasicki, the author focuses on the bishop's attitude towards Montesquieu and assesses the "recast" of the Spirit of Law in Monitor. He then describes Krasicki's political views, juxtaposing them with Montesquieu's system. He also refers to the problem of the importance of religion for the state.

The fifth and final chapter, titled "Temple of Venus in Knidos" and pseudo-classical criticism in Poland (1776-1830), deals with the reception of the play Templum Veneris by Montesquieu, published in 1725 . The piece, in essence a salon romance, was characterized by beautiful language, lightness of form and fairly frivolous subject matter. In his era the drama was appreciated by audiences, but it soon waned in importance. The author of the dissertation compares the translation of the drama known in the Age of Enlightenment - translated in to Polish as Kościót Knidejski [Kniodos Church] by anonymous ${ }^{15}$; the poetic adaptation by Szymanowski and other attempts. The author describes the role played by that drama which in case of Montesquieu is inferior and random.

The language of the doctorate is characterized by rich vocabulary, the artistry of the word is alive and does not differ from the contemporary one. The text is characterized by a calm, balanced analysis, not so much a judgement, based on a thorough reading of numerous sources from the time of the Enlightenment. An undoubted advantage of the dissertation from the perspective of the $21^{\text {st }}$ century are references to source texts, including from the $18^{\text {th }}$ century (for example, the first editions of Staszic, and the texts of graduates from the Piarist schools).

The subject of Montesquieu's entire reception had not been previously developed to such an extent. Indeed, there were studies on the author's political thought, and

\footnotetext{
${ }^{15}$ The title of the play in this case, was polonized and adapted to Polish conditions.
} 
comparing it with that of others, but no monograph on the penetration of the Frenchman's ideas into Polish intellectual circles had been published. Korzennik's dissertation is all the more valuable because upon reading it one can conclude that even a lack of awareness of its existence was a serious rift in the national intellectual continuum.

\section{Korzennik's work in the light of the concept of so-called orphan works}

Of course, as in the case of any research (which does not work in a vacuum), the lack of access to studies made by predecessors would be a great loss for researchers into Polish literature. A scientific study on Montesquieu is the starting point for further detailed research into it. It recapitulates the state of research, thus becoming a kind of digestive process. It would be a great loss if that yellowed manuscript, the only material carrier made by a Jewish researcher of scientific work - due to the corrosion of time and the material fragility of paper - ceased to exist. The possibilities of its preservation (such as in a digital form), however, have not been evident until now.

Since Majer Korzennik's war and post-war fate remains unknown, the institution holding the manuscript (Archives of the Jagiellonian University) is unable to reach the author or heirs of his copyrights in order to obtain permission to use the work outside its lawful use. The lack of a certain date of the author's death does not allow concluding whether the work belongs to the public domain (these are, for example, texts that can be used freely only after 70 years from the creator's death). Therefore, it can be considered (for the purposes of this article) that Korzennik's dissertation probably has the status (according to the nomenclature of copyright law) of an orphan work.

The issue of orphan works, defined as works whose present owner is unknown or impossible to find in the process of diligent search and the work itself is still protected by copyright (both personal and property), is one of the key problems affecting the state of scientific research in various fields, not excluding contemporary culture. ${ }^{16}$

The phenomenon of orphan works is not marginal. According to various data, orphan works constitute at least $40 \%$ of all works protected by copyright. In the case of some categories of works, especially Judaica, the percentage of works with such unknown copyright status is very high, especially for works created before 1939.

Up until 2015, there were no regulations on how to use orphan works. A breakthrough point in the resolution of orphan works is the amendment to the Polish Copyright and Related Rights Act 2015, which indicates institutions (based on Directive 2012/28/EU of the European Parliament and of the Council on certain permitted uses of orphan works), the definition of an orphan work, rules for determining the status of an orphan work and the rules of fair use of these works.

Permitted use of orphan works has been limited to non-commercial uses (not bearing material benefits) by state institutions (public libraries, state archives, state universities

\footnotetext{
${ }^{16}$ Vide A. Smywińska-Pohl, A. Jarmuszkiewicz, "Dzieła osierocone jako wyzwanie dla humanistyki", Zagadnienia Rodzajów Literackich 2017, no. 2.
} 
and research institutions, and state cultural institutions whose purpose is to collect and share collections).

The purpose of using an orphan work can only be the implementation of statutory tasks of these institutions serving the public interest (e.g. digitization and sharing of collections on-line). In order to give a work the status of an orphaned work, these institutions must carry out carefully and in good faith a search for each of the eligible persons who are entitled to proprietary copyrights (authors or heirs) prior to making the works public.

When the search has come to an end and is properly documented, and those entitled to copyrights have not been found, then the work may be entered at the request of the Minister of Culture into the orphan works database kept by the Office for Harmonization in the European Union.

These conclusions, which are simple in character, should (perhaps) be a contribution to the beginning of more intensive work in order to protect the orphaned cultural heritage from material disintegration and disappearance. Fortunately, this is now legally possible (though in a very limited scope) thanks to the amended Copyright Act.

Finally, it is worth noting a comprehensive elaboration of the topic of Montesquieu's presence in Poland was published only in October $2018 .{ }^{17}$ This fact only emphasizes how much Poland, and the world, has lost. How far could one go if it was not necessary to reopen a door that was already open; one would not have to walk again in the faded footsteps of our predecessors. Instead of repeating it would be possible to continue, and to build upon their works.

\section{BIBLIOGRAPHY}

\section{Source literature}

Korzennik, M. (1937), Gimnazjum męskie „Tachkemoni”, in: Almanach szkolnictwa żydowskiego w Polsce, Warszawa.

Korzennik, M., Montesquieu in Poland, Archiwum UJ, WF II 505.

\section{Secondary literature}

Chudoba, E., Smywińska-Pohl, A. (2017), Córki Nawojki, Kraków.

Księga Pamiątkowa III gimnazjum obecnie II Liceum im. Króla Jana III Sobieskiego 1885-1985 (1984), Kraków.

Kulczykowski, M. (2004), Żydzi - studenci Uniwersytetu Jagiellońskiego w Drugiej Rzeczypospolitej (1918-1939), Kraków.

Prokop-Janiec, E. (1992), Międzywojenna literatura polsko-żydowska jako zjawisko kulturowe i artystyczne, Kraków.

\footnotetext{
${ }^{17}$ Vide https://www.wuw.pl/product-pol-8331-Monteskiusz-w-Polsce-Wczoraj-i-dzis.html (Accessed: 14 November 2018).
} 


\section{Press}

Nasz Przeglą 13.06.1936, no. 174.

Tygodnik Żydowski 1933, no. 33.

Zagadnienia Rodzajów Literackich 2017, no. 2.

\section{Internet sources}

Matyaszewski, P., Monteskiusz w Polsce. Wczoraj i dziś, https://www.wuw.pl/product-pol-8331-Monteskiusz-w-Polsce-Wczoraj-i-dzis.html (Accessed: 14 November 2018).

Gregorowicz, G., Hachszara na ziemiach polskich, https://histmag.org/Hachszara-na-ziemiach-polskich-6131 (Accessed: 14 November 2018). 